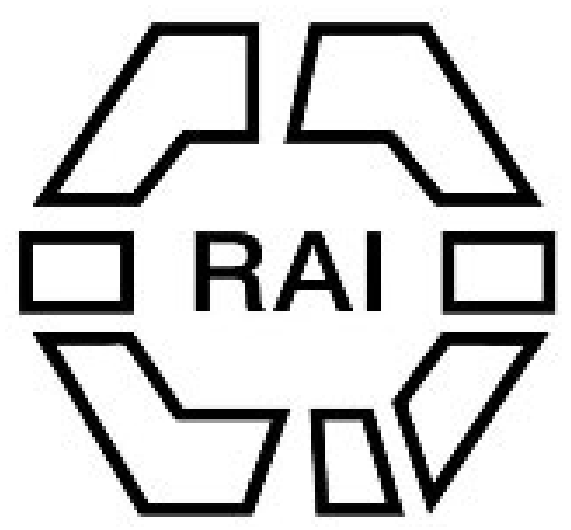

The Kalmucks.

Author(s): J. Kopernicki

Source: The Journal of the Anthropological Institute of Great Britain and Ireland, Vol. 1 (1872), pp. 401-418

Published by: Royal Anthropological Institute of Great Britain and Ireland

Stable URL: http://www.jstor.org/stable/2841274

Accessed: 14/06/2014 07:46

Your use of the JSTOR archive indicates your acceptance of the Terms \& Conditions of Use, available at http://www.jstor.org/page/info/about/policies/terms.jsp

JSTOR is a not-for-profit service that helps scholars, researchers, and students discover, use, and build upon a wide range of content in a trusted digital archive. We use information technology and tools to increase productivity and facilitate new forms of scholarship. For more information about JSTOR, please contact support@jstor.org. 


\section{ANTHROPOLOGICAL MISCELLANEA.}

\section{THE KALMUCKS.*}

Name and Origin.-The etymology of the name Kalmuck is interpreted in different ways. Some derive it from the Tartar Khalimak, which is as much as to say He who remains behind; others deduce it from two Mongol words, Ghol (fire) and aïmak (tribe); from whence Ghol-ä̈mak, Khalmak, and lastly Kalmuck, i.e., Ardent People. The Kalmucks primitively inhabited the countries north-east of the Chinese empire ; viz., Dzoungarie : and participated in all the conquests of Djenghis Khan and of Batou in the east. At the commencement of the seventeenth century, they arrived on the shores of the Caspian Sea ; and they have camped there to the present day in the immense steppes which extend on the right of the embouchures of the Volga.

Physical Characters.-The first glance of a Kalmuck suffices to recognise in him the model representative of the true Mongol type. They are of middle stature, robust and broad in the shoulders. Their skin is swarthy, face flat, fissure of the eyelids narrow and oblique, nose depressed, nostrils wide, lips thick, teeth white and regular, ears long and prominent, hair black, and beard thin.

Psychical Characters.-The principal trait in the character of the Kalmucks, after their simplicity, want of cleanliness, and laziness, is that, after the manner of all nomade people, they are extremely superstitious. The Kalmuck never undertakes any serious matter without having previously consulted a sorcerer. He never dares to kill a fly for fear of assailing the soul of one of his ancestors, which may perhaps animate this insect. When, on a journey, a Kalmuck perceives a certain bird which he esteems to be a good augury, he rejoices in this conjuncture, does not fail to manifest his satisfaction, and bows himself three times. As soon as he perceives a hare, on the contrary, he utters a cry, pursues it, and strikes a blow in the

* This notice of the Kalmucks of the Volga is translated from the Russian work entitled " Russia in Europe, under its Physical and Ethnographical Relations." By B. Liadov. St. Petersburg, 1861. It is considered to have been derived from another Russian author, Nebalsine. Nebalsine resided for a long time at Astrakhan, at the mouth of the Volga, on the Caspian Sea, and was employed at the "Court of Domains", which governs the Kalmucks. At this place he had occasion to study this people carefully and intimately; consequently, he is regarded as a great authority upon the Kalmucks. His account of them was published probably twenty years ago. The article now printed is vastly more complete than that upon the Kal. mucks in the great work of De Pauly, "Les Peuples de la Russie." 
air with his stick, in order to exorcise the misfortune which might happen. For the world he would not pick up a steel for striking a light found upon the way. To seat himself upon the threshold of the door, or warm his feet before the fire, he holds for a great impiety; and if it happens to any one to light his pipe with paper, it is certain that he will soon die.

Notwithstanding these superstitions of the Kalmucks, they are said to possess a good deal of intelligence. Their imagination especially is much developed, and they are sufficiently ingenious, which is proved by their tales and proverbs. Some of their tales are so long that they require many evenings to be recited to the end. They are, moreover, distinguished by their peculiar form, and they are not related in ordinary manner, but the Kalmucks recite them in a singing tone.

As to the proverbs of the Kalmucks, it is impossible not to recognise in them the sound judgment of this people, and their acuteness.

"To get a sheep, ask for a camel."

"It is better for a cypress to be broken than to be bent; and for an honest man it is much better to die than for him to degrade himself."

"Ill-got food sticks between the teeth."

"In the desert, of a beetle is made a sheep."

Mode of Life.-Being exclusively occupied in raising cattle, the life of the Kalmuck is nomade. A "lkhoton", which is a commune, more or less numerous, composed of many families united by bonds of relationship, never remains more than two or three weeks in the same place. Transmigration from one place to another is a real feast to the Kalmucks. All their goods, including their tent, kibitka, are loaded upon the back of a camel, and covered over with a piece of drapery if the family is in easy circumstances. The women and girls, in holiday dress, as well as the young boys, drive the flocks. The little infants are placed in panniers, which are attached to the sides of the loaded camels, and the mother who is suckling is mounted on the top with her infant. The men on horseback take the lead, and conduct the caravan. The march, which sometimes lasts many days, does not tire the Kalmucks; and they often divert themselves with songs and stories.

Behold them at last arrived at a spot which affords more abundant pasturage. They make a halt, unload the camels, and set to work to erect the tents, which does not require much time. At the end of half an hour, the framework of the kibitka is put up. It has the form of a truncated tunnel reversed, resting by its base upon a cylindrical support, which has the same circumference. The kibitka is covered outside by a felt cloth, and inside with reed mats. At one side there is an opening, into which is fitted a wooden frame for the door. This door, being open all day, allows the air and light to enter into the interior of the tent, which also receives a little light from above by an opening in the centre of the roof. The floor of the kibitka is covered with a carpet and felts in summer, and with the skins of different animals in winter. The arrangement of the inte- 
rior of a kibitka does not require much pains or time. Opposite the door they put up against the side of the tent a low couch. On the left of this is raised the grand "baran", the most sacred place in the habitation of a Kalmuck. It is upon this that the objects of his religious adoration are deposited, as well as all the treasures of his family. Upon the spot in which this great baran is to be raised, they first spread the coverings and caparisons of the horse equipage and saddles; upon these are placed coffers with clothes: all these being covered over with a drapery, they deposit last of all the trunks in which are kept the bourkhans, the Kalmuck's idols. These being withdrawn from the trunks and placed upon the draperies, a sort of altar is raised before the bourkhans. It is a little wooden table, upon which they arrange many little dishes of silver and copper, intended to receive offerings, cheese, gruel, and different kinds of incense. Lastly, before this little table they plant in the soil a piece of wood surmounted with a small silver cup. It is in this that the head of the family deposits the first morsel of every dish that is eaten during the common repast.

On the right of the door, opposite to the preceding, the little baran is raised. Here they place the largest coffer, upon which are placed the provisions, wine, and the best household utensils. Around this coffer they place the kettles and other cooking vessels.

The entire arrangement of the kibitka, both outside and inside, is the affair of the woman. The husband only charges himself with the construction of the framework, and with some definite corrections which may be necessary. He passes his time in the chase, in pasturing his flocks, or simply doing nothing. All the charge and cares of the household belong to the woman.

Manners and Customs of the Family.-In the family life of the Kalmucks, the marriage of a son or daughter is a principal occasion of rejoicing and of feasts. The choice among the Kalmucks belongs entirely to the parents. Still, there is no constraint upon this point, and, if the son declares that the selection of his parents displeases him, there is no further question about the matter. In considering marriage as the most serious and grave act of life, the Kalmucks never undertake it without the benediction of their "ghélung", priest. As soon as he, after having consulted the constellations under which the affianced were born, declares that there are no obstacles to their marriage, one of the elder relatives, on the part of the boy, repairs to the parents of the girl, and, after having regaled them with eau-de-vie, announces the object of his visit. It is rare that a refusal takes place in these cases. The parents having given their consent, may expect the formal demand in marriage. Some days afterwards, the father of the affianced youth, having taken with him a provision of wine, a sheep, a block of tea in the form of a brick, and a roll of paper containing a strap and a piece of fish-glue, accompanied with many friends, who ought to be absolutely married, repairs to the khoton of the betrothed girl. Having arrived in the kibitka, he begins by serving out the wine to all present; then he brings up the sheep, which his friends 
kill, and immediately put it into the cauldron to be boiled. The little packet, containing the tea, the strap, and the glue, is presented to the father of the affianced girl. The tea is consumed at once, and the two other objects, which represent the jewels of betrothal, are deposited on the little table before the bourkhans.

The demand in marriage is shortly followed by betrothal, which consists in the youth repairing to the khoton of his intended bride, and offering her presents of dresses and stuffs. This, which takes place without anything particular being said, gives occasion to a fresh banquet. Between the betrothal and the marriage, there sometimes elapses a whole year, or even more. During this long interval, sometimes the youth, sometimes his parents, come from time to time to see the affianced. When she has completed her sixteenth year, the parents of the youth address the ghellung, beseeching him to fix the propitious and happy month and the day for the celebration of the marriage. Afterwards, some days before the date fixed, the whole family of the young man go to the tent of the betrothed. The first day of their arrival passes in doing the honours of reception; the next day the parents of the youth declare to those of the affianced girl their desire that the ceremonies of the marriage should be accomplished, and, at the same time, they endeavour to learn, in an indirect manner, to what sum the expenses on the part of the young man would amount, and what feasts ought to be offered to the most notable guests, to the acquaintances and the parents of the girl. They never speak of dowry, since the woman ordinarily receives everything necessary for housekeeping.

The day of the marriage, the young man, with his assistants, well provided with wine and viands, repairs to his future father-in-law, where they make a great feast. When the feast is concluded, he is invited into the kibitka of his betrothed, where is exposed her entire dowry, which they shortly send to his khoton. Sometimes the entrance to this kibitka is guarded by the companions of the betrothed, armed with sticks, so that the youth often has great difficulty in gaining an entrance. In order to avoid the blows which threaten him, he offers sweetmeats to the guard. When this guard is satisfied, the young man carries away his betrothed from the kibitka, places her behind him upon his saddle, and repairs to the khoton of his parents.

Here there has been early prepared a kibitka to receive the newly married people, and it is before this that the following marriage ceremony is performed. Before the entrance they spread a carpet, and upon this is put a quilt of white felt. Behind the carpet is found the table with the idols, before which is placed, in an offering dish, a shoulder of mutton, as an emblem of riches. The affianced, surrounded with acquaintances and relatives, place themselves before the table of the bourkhans, the ghelung recites many prayers, after which he seats himself upon the carpet, takes the fold which veils the face of the girl, envelopes in it the shoulder of mutton, and presents it to her. The young man takes it in his left hand and his betrothed in the right. Then the ghélung, after having pronounced many more 
prayers, raises the two affianced up and recommends them to bow three times to the earth. They execute these motions without relinquishing the shoulder of mutton, which they continue to hold in their hands, and, in making each reverence, they pronounce the following words :

"I incline myself this first time to adore my Lord God, who is my father and my mother."

"I incline myself this second time to adore my Sun, which is the light of my beloved day; and my Moon, which is the light of my beloved night."

"We swear to love one another, to respect one another mutually, and to partake in common of all the trials and all the joys of our life."

After which, the ghellung having taken an idol from the table and touched the beads of the couple, the principal and essential portion of the ceremony is finished.

The rest is accomplished in the interior of the kibitka. Having entered, the affianced incline themselves three times before the bourkhans, and seat themselves in their places, the youth on the bolster of the bed, and his affianced at the other end. After which, all the acquaintances enter and occupy their places. The ghélung takes the shoulder of mutton, cuts the flesh in pieces, and distributes them to the betrothed and their parents : the viand is consumed instantly; and the bone is preserved as a sacred thing, as a pledge of the future happiness of the new family.

Having accomplished all this, the ghelung retires, and the party devote themselves to the rejoicings they have been so long expecting, which are prolonged two or three days. Among these entertainments during the marriage feast, an indispensable part is assigned to wrestling, which is an exercise much esteemed among the Kalmucks.

The marriage ceremonies among notable Kalmucks are conducted rather differently; yet the difference only consists in this. Ordinarily, it is not the youth in person, but one of his nearest relations, who is charged with conducting his betrothed. The young man meets her on the way, and it is at this place that the principal ceremony of the marriage is accomplished. Arrived at the kibitka of her husband, the girl does not descend from the horse until she is taken off in his arms. Afterwards her horse is set free, and passes into the possession of him who first catches it.

In that which concerns the position of the woman in the Kalmuck family, it is much superior in comparison with that which occurs among other people who are on the same level of civilisation as the Kalmucks. The law, consecrated by usage, in making the Kalmuck woman full mistress of the household, determines strictly what ought to be the conduct of the man. The man has not only no right to raise his hand against a woman, but he is obliged, on the contrary, to treat her with respect. Thus, for example, in inviting a woman to dance, he ought to kneel, and carry his hand to his forehead, and afterwards to the knee of his wife. She, on the other hand, in inviting one to dance, has only to incline herself gently, and to touch 
his shoulder. A man is not permitted to refuse a dish or a drink which is offered to him by a woman. Also, upon a journey, if he perceives that a woman intends to descend from her horse, he is expected to get off immediately to assist her to descend.

Such are the laws and usages of the Kalmucks with respect to their women; but, at the same time, these laws are not observed very strictly. The Kalmuck treatis his wife with consideration only in the presence of other persons. When alone, it often happens that he beats her, not only for some omission or negligence on her part, but, for example, for having carelessly trodden upon the foot, the gun, or the stick of her husband, or even for having caught him with her skirt.

Divorce is equally forbidden by law, but usage gives the husband the right to send his wife back as soon as she displeases him, and that without assuring her the means of subsistence. In case a Kalmuck abandons his wife in an honourable manner, he gives an especial entertainment, to which all her relations are invited. When the repast is ended, he orders a horse ont, ready saddled, to carry back his wife to the khoton of her parents.

Besides the cares of the household, the Kalmuck woman is charged with the education of her children. The birth of a child among the Kalmucks does not give occasion to any particular ceremonies. Scarcely has the new-born child come into the world, when it is carried out of the kibitka, and the first object which then presents itself to the eyes-dog, sheep, serpent, or other-yields its name to the infant. Sometimes the ghelung is invited to give it the name which he finds in his book. Besides which, each Kalmuck bears a certain soubriquet ; for example, badma, flower, narbo, jewel, etc.

The Kalmucks do not reckon their age from the time of their birth, but by a peculiar calculation. Thus, the day of the new year (Nov. 24-Dec. 6) being the general birthday, they reckon that a child born, if only a few days, before that day of the year is two years old. The Kalmucks trouble themselves very little with the education of their children. As soon as a child begins to walk, he is abandoned to himself, and he habituates himself gradually, by his own experience, to all the privations of a Kalmuck existence. When arrived at the age of eight years, the boy is sent to some ghélung to commence his studies. These consist in learning to read and write and endure for two or three years. The master is paid by means of presents received from the parents at the commencement and at the termination of the course. The girls of the Kalmucks, as well of the poor as of the rich, do not learn to read or to write. A girl having finished her thirteenth, and the boy his fifteenth year, they convoke the near relatives, and invite the ghélungs. After a short prayer before the bourkhans, the boy or girl having attained majority is introduced, and his or her hair clipped on the temples. From this moment they are considered marriageable, and they shortly become betrothed.

The religion of the Kalmucks is Lamaic, or Buddhist. The doc- 
trine of Buddha, undergoing corruption among the Kalmucks from generation to generation, consists at the present day of a most absurd mixture of credences.

According to their ideas, before the creation of the universe, there existed an enormous abyss, which was thirty millions of kilometres* in depth, and eighty millions in breadth. From the bottom of this abyss there came out golden clouds, which afterwards condensed into a cloud charged with lightning, and then melted into abundant rain, which formed the ocean. This ocean was nearly nine millions of kilometres in length and ten millions in breadth. In time the winds gradually formed a great quantity of froth on the surface of the ocean, and of this froth the continent was formed. In the first place, there appeared the mountain Summer, which is more than three hundred thousand kilometres in height. Upon the top of this gigantic mountain, of which we only see the half, is found a vast plain. The mountain itself has the form of a rock with four flanks. Each side of the mountain has a different colour: silvered on the side of the east, red on the west, blue on the side of the south, and golden on that of the north. Around the Summer are found four great islands, which form the four parts of the world. The isle of the south is that which we inhabit; that of the east is peopled with men who live one hundred and fifty years; the isle of the west, which abounds with cattle, is inhabited by giants ; lastly, the isle of the north is peopled by peculiar beings-they each live one thousand years, and the end of their lives is announced to them by an unknown voice. Besides these four principal islands, there are also seven other smaller ones, and as many seas.

The first inhabitants of this world were divine beings, called Tingheris. These Tingheris primarily inhabited the seventh heaven, but at one time they lapsed into quarrel and into war one against the other. The good conquered; and the wicked Apouris were forced to quit heaven, and they installed themselves upon the summit of Summer. Nevertheless, the contest begun in heaven always continued, and the number of fugitive Tingheris increased so that they occupied all the islands which surrounded the mountain Summer. At the commencement of their terrestrial life, the Tingheris preserved their divine qualities. Thus, for instance, they each lived eighty thousand years, their faces were luminous, they possessed wings wherewith to fly, they went without food, etc. But one day there appeared upon the earth a certain fruit named "shime", which was as sweet and as white as sugar. As soon as men tasted it, they lost all their qualities of perfection; the brilliancy of their faces disappeared, their wings fell off, they felt the need of nourishment, and the duration of their lives sank to 10,000 years only.

As long as men had luminous faces, there was no reason or necessity for the existence of the sun and moon. But, as soon as the shining of their faces was extinguished, obscurity spread over all the earth. Then four benevolent Tingheris, named Wishna, Mandi,

* A kilometre and a little more than half ( $1 \cdot 6$ kilometres) is equal to an English mile. 
Oubba, and Lukan, having taken pity on the human race, and having seized the Mount Summer in their arms, shook it so violently that the ocean of the universe was agitated, in consequence of which there appeared the sun, the moon, and the stars.

The sun, according to the doctrine of the Buddhists, is a globe of crystal, being more than 1000 kilometres in circumference. In its interior there is lodged a luminous Tingheri, whose radiant face spreads light and heat over all the earth. The sun is placed in an enormons plain, all covered with the most splendid flowers. Every twenty-four hours seven aerial horses draw it round Mount Summer. In the morning the rays of the sun fall upon the silver side of Summer, before noon upon the blue side, at noon upon the golden side, and lastly, in the evening its red side is illumined. Afterwards the sun hides himself entirely behind the mountain, in consequence of which darkness and night ensue.

The moon, according to the ideas of the Buddhists, is also a globe of crystal, but filled with water, and it also is inhabited by a luminous Tingheri. The phases of the moon depend on its more or less remoteness from the sun ; and the spots which are perceived on its surface are the shadows of the different marine animals which live in the universal ocean. After having created the sun and the moon, the creative gods held a council, during which "Arakho", the wicked spirit, glided in unperceived, and drank up all the sacred water of the vase which stood before the gods. Indignant at this audacity, they decided to punish Arakho, but for a long time they could not discover where he was. They then interrogated the sun, and the sun gave them an unsatisfactory reply. They then addressed themselves to the moon, and she indicated to them the place in which Arakho was hidden. In revenge for this Arakho had frequent quarrels both with the sun and the moon, and sometimes he fought with them. During these duels there was an eclipse upon the earth.

The stars, likewise, are equally great globes of crystal, inhabited by Tingheris. One only among all the stars-it is the pole star, called the "pile of gold"-is fixed. All the others, to the number of two hundred and twenty-five millions, are transposed by aerial horses from one place to another. The fall of a star signifies the death of a Tingheri, whose soul then descends into the abyss to animate another body.

The change of seasons is produced by a winged dragon. During the whole of winter it is in repose, lying upon the seven seas. In summer it rises up with the vapours, and ascends towards the upper strata of the atmosphere. The 'Tingheri which rides this dragon excites it from time to time to thunder and to vomit flames. From time to time also this Tingheri himself shoots from heaven fiery and deadly arrows.

As to the past destinies of the human race, the Buddhists teach thus. Men, having tasted the fruit "shime", could not any longer do without nutriment; and, since the shime could not suffice for them all, they began to feed upon terrestrial honey and some vegetables. 
The fear of the want of food has forced every one to think only of himself, and to seek to provide for the future. Indigent people began to envy those who were richer. The discord which arose among men forced them to choose chiefs charged with their well-being. These chiefs abused the confidence placed in them, and, supporting themselves upon their power, changed into despots.

In proportion as iniquities multiplied among men, their longevity decreased more and' more, and at length arrived at its present degree.

During this period of continual calamities, many bourkhans, clothed in human form, descended from time to time upon the earth, and preached penitence and correction. There were four of them; and the last of them, named Shakiamouni, is recognised as the founder of Buddhism. He taught his doctrine to sixty nations, each one of which understood it differently, which has occasioned the origin of so many different religions that prevail upon the earth.

As to what concerns the future destinies of the human race, they teach that the stature and the age of men will sink by degrees, and that there will come a time at which human stature will not exceed one "arskine", which is about twenty-eight inches and a half. Then each child will speak immediately after its birth, and the next day it will be capable of undertaking its own management. They will marry at five years of age, and will not live longer than ten years. The human race having arrived at such a state will be the sign that the moment of universal destruction is at hand. Seven years before this cataclysm, the earth will become completely sterile, and the greater part of mankind will die. Afterwards a great number of swords will be cast down from heaven, which will put to death the rest of the survivors, excepting a single just farnily, which will be hidden in a ravine. After which the earth will be covered with dead bodies and gorged with blood. It will rain a purifying rain, afterwards a fecundating rain; lastly, a third rain will bring all that is indispensable to man. The family which was hidden will then come out from its refuge, and many other virtuous men will be resuscitated to recommence their new life, which will endure eighty thousand years, and to enjoy all the blessings of the earth.

But shortly men, forgetting past misfortunes, will begin again to do evil, and consequently their longevity will be gradually decreased. When human life will not endure more than two thousand years, there will appear upon the earth the bourkhan Maïdari. He will be of high stature, and of dazzling beauty. Men, surprised with his exterior, will ask him by what means he had arrived at such perfection. To which Maidari will reply, that all this came to him in consequence of his good works, by which they also are capable of gaining the same perfection. The example and the instruction of God reacting upon men, they will be corrected, and they will live anew eighty thousand years. This second change will be followed by fifty-four new ones; and each eighth change will be accompanied by a deluge, all the others by a fire.

The Buddhist doctrines of the soul, of punishments and rewards VOL. I. 
which are prepared for every one after death, are equally very strange. The souls of all creatures pass after death into new beings. Each soul prepares itself for this transmigration during its terrestrial life. Dwelling in the human body, the soul never seats itself in one single definite place, but every day changes its seat. Thus, on the first of each month the soul finds itself in the forefinger; the second day it resides in the foot; the third day in the calf of the leg; the fourth in the knee. In this way it ascends every day higher; at the eighth day it finds itself in the loins; the twelfth it passes into the palm of the hand; the fifteenth it spreads through the whole body; the sixteenth it seats itself in the nose ; and on the last day of the month it appears in the thumb. Afterwards its migration recommences in the same order. The injury of a part, when the soul is seated in it, is always followed by an inevitable death. After death, the soul passes into one of the six reigns, and animates some other body. These reigns are the following : 1 , of good tingheris ; 2 , of "assouris"; 3 , of men ; 4 , of beasts ; 5 , of "birides"; and 6 , the reign of "taman", or that of eternal pains and sufferings.

The choice of such a reign, or of another, does not depend upon the soul itself, but it is fixed by the judge of the lower regions, who takes into consideration the good works accomplished upon earth. The habitation of the judge of the infernal regions, called "Erlik-Khan", is situated in a subterranean palace, surrounded with sixteen walls of iron. It is there that all the souls of dead men present themselves before him, except those of lamas, which ascend at once towards the much happier dwelling-place of the tingheris. Each soul is escorted by two spirits, the good and the wicked, who, presenting it to Erlik-Khan, place before him white and black stones. If the white stones, which signify good works, exceed the black, then the soul, placed upon a golden throne, ascends to the kingdom of the tingheris. In a contrary case, it descends to be purified in the kingdom of the birides, which is divided into thirty-six sections. The inhabitants of this kingdom remain there five hundred years at least, and every day of these years is equal to one of our months. The souls here undergo pains more or less severe, according to the nature and the degree of their crimes. Thus, cruel chiefs and homicides are condemned to swim without rest in a sea of blood; misers, transfigured into monsters, having a mouth as small as the eye of a needle and a throat as fine as a thread, have nothing but flames upon which to feed and blood to drink. These poor damned continually rove over a desert plain, seeking in vain some nourishment. They sometimes perceive trees full of delicious fruits, but scarcely do they happen to approach them than the trees disappear, and the unfortunates behold themselves again abandoned to their punishment in the midst of the desert.

The punishments practised in the kingdom of Taman are still more terrible. Taman, situated at 200,000 kilometres below the earth, is divided into sixteen sections. In the first, the damned, half dead, are continually cast from knives to knives; and this punishment 
endures for five hundred years, of which each day further equals nine millions of years. In the second section, the condemned are continually sawn. In the third, they break them in an iron press, and every time they revive they are bruised again. In the fourth and fifth sections, the condemned are roasted by the fire. In the sixth, they are boiled. In the following, they are frozen to the degree that their skin is covered with blisters, their lips split into shreds, etc. Not only men, but animals also, are condemned to undergo different pains. Thus, some are condemned to bear different burdens; others to run without rest, and to be torn in pieces by ferocious animals.

Just as the punishments of hell are terrible, so also the enjoyments of paradise, prepared for the just, are delicious. The paradise of the Buddhists is divided into five regions, each of which bears the name of one of the principal bourkhans.

The first, kingdom of Abiddhabati, is full of trees of silver, with branches of gold, which bear, in the place of fruit, stones the most precious. Streams of living water irrigate this miraculous country, in the midst of which is found a delightful forest, in which the bourkhan Abiddhabati, surrounded by the just, reposes upon a throne, which is supported by a peacock and a lion.

There are others of the just men whose souls inhabit the top of Mount Summer, where the bourkhan Khourmousta rules over thirty and three tingheris. The residence of Khourmousta, about 20,000 kilometres in circumference, has 170 gates, each guarded by 500 warriors in arms. The royal palaces, situated in the centre of the capital, are surrounded with gardens, in which the miraculous elephant wanders and feeds. The habitation of the happy souls, situated not far from the royal palace, is remarkable for its tree, as miraculous as the elephant. The trunk of this tree rises 800 kilometres above the earth ; its branches are covered with leaves, each of which is nearly 40 kilometres in circumference, and the perfumes which are diffused from its flowers are perceived at a distance of about 400 kilometres.

Besides Khourmousta, there are also other divinities who dwell in Mount Summer. The number of the gods recognised by the Buddhists is infinite. They are divided into tingheris, bourkhans, and raghignes. The tingheris have existed from the origin of time, and inhabit the seventh heaven. The discords which have happened among them have forced many of them to descend into the inferior celestial regions, and afterwards to the top of Mount Summer. The tingheris are divided into good and wicked. The latter, as more dangerous, are more respected. The duration of the life of the tingheris differs. Each of those who inhabit the summit of Mount Summer will live 3,700 human years. Those who dwell a little lower have to live 500 years only, each day of which is as long as 500 human years. Those, lastly, who $d$ well in a region still lower will live still less long.

The Bourkhans are equally divinities, but of an inferior dignity, to which every man may rise by means of his good works. The Bourkhans sometimes descend upon the earth to preach penitence and amendment. Their number is very considerable. The first rank re- 
turn to Buddha, or Shakiamouni, the founder of Buddhism. It is represented under a figure of a man in contemplation, seated upon the mountain Boudalah, in Tibet. Round this mountain are found dispersed rich forests full of fruit trees, and further plains extend covered with fields of rice.

The second rank among the Bourkhans is assigned to "Maïdari," who is governor of the future world, as Buddha governs the actual world. Maïdari is figured yellow, with a red scarf round his body, and his hands crossed upon the breast.

Among the other Bourkhans the most important are the four following: "Mantsoshiri," "Khourmousta," "Erlik-Khan," and "Yamandagha."

Mantsoshiri means eternal yellow. They recognise him to be the father of a thousand other bourkhans, and he is to be the governor of the world after Maïdari. They represent him with four hands, one of which holds a golden sword, the second a book of wisdom, and the two others bless the world.

Khourmousta is recognised as the supreme patron of the earth, and is represented under the figure of an old man, or, according to others, under the figure of a little boy, who mounts the elephant, and holds a sword in his right hand. This elephant is called the son of the defender of the earth. He is white, and is 20 kilometres in length. The pasture of this giant is a forest situated round a lake, which is 10,000 kilometres in circumference, and contains water sweet as honey.

When Khourmousta is disposed to make a promenade upon his elephant, then upon this last there appear in an instant thirty and three heads, each of which is armed with seven tusks. Upon each tusk there are seven lakes, in each lake seven beautiful virgins, each accompanied by seven attendants, who sound cymbals. Khourmousta himself is seated upon the principal head, which is in the midst, and upon the other heads are placed the thirty-three tingheris, his subjects. The cortège is accompanied by five thousand cavaliers, who also mount as many elephants.

Erlik-Khan has his sojourn in the kingdom of the "birides." Formerly he reigned in one of the superior worlds, but he was expelled by "Yamandagha." Erlik-Khan is represented standing upon the back of a furious buffalo. All round his body are suspended the heads of the dead. He holds a sceptre in one hand and a cord in the other.

Yamandagha, the conqueror of Erlik-Khan, is the most repulsive and frightful of the bourkhans. They represent him surrounded with flames and having thirty-six arms, which hold weapons, the heads of the dead, and serpents. Sometimes he is represented simply under the figure of a man with glaring eyes, staring teeth, and fire issuing from his mouth. His cincture is composed of a file of human heads, and upon his knees he holds a repulsive woman of a blue colour, who treads under her feet different monsters and men.

Besides the bourkhans who have been named, there is a multitude of others. It is remarkable that they represent them all seated, 
crouching upon their feet, and they all have feminine physiognomies.

The "Raghignes" are divinities of the female sex, and have power equal to the preceding.

The chiefs of the Buddhist clergy are the Dalai-Lama and the Bogdobatsin. They both reside in Tibet. Formerly Dalai-Lama exercised the civil and spiritual power in the whole of Tibet. But since 1703 , that is, since that country has passed under the power of China, Dalai-Lama has not only lost his civil power, but he has been obliged to divide with Bogdobatsin his spiritual power also. Notwithstanding, Dalai-Lama always exercises an enormous authority. He inhabits the palace which is constructed of stones proceeding from Mount Boudalah (a sacred mountain of Tibet), and contains nine hundred and ninety-nine chambers. At a kilometre and a half from this palace stands the celebrated temple Dshu. Every new year there assembles in this temple the clergy of the whole of Tibet, to the number of seventeen thousand men. They celebrate there day and night divine service for twenty-one days.

All the rest of the clergy is composed of Lamas. To become a lama is not an easy thing. For this, besides the three principal books Danjour, Ganjour, and Youme, it is necessary to read a multitude of others, which embrace many hundred volumes. It is also necessary to be instructed in astronomy, in medicine, and in other sciences; and lastly, which is the most difficult, it is necessary to perform the vote, to think upon God every moment, and strictly to execute all the commandments, the number of which surpasses two hundred.

The Social Organisation of the Kalmucks at the commencement of the seventeenth century, that is to say, at the epoch of their arrival in Russia, was purely patriarchal. Many families united by the bonds of relationship formed a khoton, of which the most aged was the head, and was called "Aga."

Many Khotons composed an "Ä̈mak," governed by the "Zaïsangh," the power of whom was hereditary from father to son.

Afterwards many Aïmaks in their turn formed a commune, and many communes composed an "Oulouss," governed by a "Nohyon," or chief.

Lastly, a certain number of Oulouss, united under the commandment of a "Taïsha," formed a tribe. The Taïsha, who had the rank of a prince, governed personally in the principal Oulouss ; and all the others he ceded to his sons and brothers, who governed there by turns. All the tribes united constituted the entire people, commanded by the Khan. After a certain time the dignity of Khans and of Taïs ceased to exist, and there remained only the Nohyons,

The actual rule over the Kalmucks belongs to the Court of Domains, at Astrakhan. This has under its direct dependence all the Noyons, to whom are subordinated the Zaïsanghs and the heads of the Khotons. The Noyons have the power of inflicting punishment for crimes.

Formerly there were three kinds of punishment-corporal punishment, fine, and the degradation of the criminal in the face of the 
Khoton, or of the entire tribe. Thus, for example, for disobedience to parents, as well as for rudeness or insolence to elders or chiefs, they applied to the offender, first, a certain number of blows with a stick, and then, after having daubed his face with soot, and tied a pan round his neck, they promenaded him through the whole Khoton. This chastisement is called degradation by means of the hand, because, to apply it, he who is charged with its execution, takes a handful of soot from the bottom of the pan, and spreads the whole handful over the face of the offender. For a theft they punished the thief by promenading him equally through the khoton by a cord round his neck. Those who met him gave him blows with a rod on his naked body, and some deride him.

The exercise of justice has three degrees: the first, which was practised in the Khoton, had a family character. The second consisted in a veritable tribunal, named "Zargo," and was composed of the Zaïsanghs under the presidency of a Nohyon. Lastly, the supreme tribunal, after the number of its members called Judgment of the Eight, was composed of the Nohyons, under the presidency of the Khan. In this supreme tribunal were judged all criminal affairs of every nature. Murder was considered as the gravest of crimes. In the eyes of the Kalmucks it was a frightful sin, and absolutely unpardonable. For murder committed for the first time, the offender paid a fine, judicially decreed to the parents of the person killed, in the manner of a retribution. Besides which, he was obliged to renounce every kind of enjoyment during a certain time, to carry a red scarf round his shoulders, and to do penance during some time near a "Khouroul," or temple. For a second murder, the fine and the penitence were heavier, and further, the criminal was marked on the face. Lastly, he who had committed a homicide for the third time, was marked on both sides of the face, and expelled for ever from the midst of the people. In case the condemned had not the means of paying the fine, he was surrendered in person to the disposal of the relations of his victim, who had the full power to employ him in any kind of labour, as well as to sell him, or to exchange him for a flock of sheep.

In the case in which there was no confession on the part of the accused, or of failure of sufficient proof to establish the crime, the tribunal had recourse to the oath of justification. The most important form of such an oath was the "Shakhan," which has not existed for some time. To accomplish this appeal, the accused, who was submitted to the Shakhan, might choose an adversary, who was generally recknned an honest man. For the accomplishment of this act, they prepared a kibitka, in which, upon an elevation, a bourkhan was exposed, before which they lit a perfumed taper. On the two sides of the bourkhan, they raised the images of punishing beings, under which were arranged the Ghelungs, with their musical instruments, employed in divine service. Upon the floor of the kibitka they spread the skin of a cow, quite black, recently skinned, and moistened with the blood of the immolated beast. Above, and to the right of the door, 
inside the kibitka, they suspended the head of the same cow. Its eyes were opened wide, the tongue drawn out and turned to one side. On the left of the door they suspended a human skull, and below this last they placed a loaded gun with its lock tied up. Outside the kibitka, on the two sides of the door, were placed the judges, the accusers, and the accused.

All these preparations being made, the person chosen by the accused for an adversary was first obliged to persuade the parties to be reconciled, in order to avoid the necessity of so great and solemn an oath. If this exhortation had no success, then they proceeded to accomplish the shakhan, which took place in the following manner. The accused who has to swear, being undressed to his shirt, placing himself upon the bloody skin of the cow, after making three profound bows, ought to jump over the threshold of the kibitka. Scarcely has he made the first movement to advance, than the Ghelungs begin to sound their trumpets, little bells and metallic plates, to blow into shells, etc. These solemn sounds accompany the oath at the table upon which the bourkhan rests, and this music is only interrupted by the slow recitation of prayers. Naturally, all this ceremony must react strongly upon the imagination of the accused; but when the accusation is unjust he is not in the least confused, and comes without fear to the bourkhan; he extinguishes the lighted taper before the idol, after which, inclining himself towards the table, he seizes the heart of the cow with his teeth, which was exposed there upon a dish, and carries it out of the kibitka. Here one of the Ghelungs receives this revealing object from him, and passes it to the judges to be inspected. If, on inspection, there are no injuries observed upon the heart, then the accused is acquitted, and the accuser is condemned to a fine fixed upon beforehand.

All this mysterious ceremony would impress the Kalmucks deeply by its solemnity, and inspire them with sentiments of terror. And this so much the more easily, as each detail of this Shakhan had a certain symbolical signification. Thus, the black cow was the symbol of death, which ought to recall to the person taking the oath the enormous responsibility to which he exposed himself; if he had taken a false oath. The charged gun, with the lock bound up, signified that the perjured ran the risk of being immediately struck by divine justice. And the head of the cow, monstrously disfigured, ought to recall to him that his soul would be excommunicated from the midst of men, and driven into some frightful and monstrous being. The idol of the bourkhan spoke to him of the presence of the supreme judge, who listened to his oath. The illuminated taper signified the divine light spread abroad by the Creator, and its perfume signified the grace of God, both of which the perjured renounced and deprived himself of voluntarily in extinguishing the taper. Lastly, the heart of the immolated cow signified the innocence of the person swearing, and the purity of his intentions.

Of all this terrible oath there remains at the present day but a very small portion only in use. In doubtful and very grave cases, 
the Kalmuck, who has to justify himself by means of the oath, only approaches to the table of the bourkhan, before which he prostrates himself three times to the earth, and, after pronouncing with a loud voice, "I am innocent !" he extinguishes the taper, to express that he renounces the favours of the Creator if he has lied. Such an oath is very serious, and appears to be the only relic which testifies to the ancient régime proper to the Kalmucks. At the present day their ancient judgment, as well as the punishments of former times, are abolished, and the Kalmucks are judged according to the common laws of the empire.

As to their actual chiefs-the Nohyons-these have preserved to the present day the same authority in the eyes of the Kalmucks which they formerly possessed. A Nohyon is respected not only by his subordinates, but by all the other Kalmucks. They dare not enter into his kibitka without having first made a sign of reverence, which consists in him who is entering touching with the palm of his hand the door of entrance, and afterwards his own forehead. In withdrawing from the kibitka they march backwards, in order not to turn the back upon the chief. If a Nohyon permits his subordinate to sit in his presence, this person thanks him by carrying his hand to his forehead ; afterwards he places himself upon his knees, and resting his two hands there, seats himself lastly upon the soles of his feet. The respect and the attention of the Kalmucks towards their Nohyons manifest themselves also in the numerous presents they are obliged to offer to them on every occasion. If it be the spring that is come, is it the summer which has arrived, is it a new child born to the Nohyon, the Kalmuck does not fail to carry him some tea, mutton, even silver coin, in sign of his congratulation.

The clergy enjoy among the Kalmucks a respect equal, if not superior, to that which they manifest to their Nohyons.

The supreme chief of their clergy is a lama. Up to the year 1800 he was always instituted by the Dalai Lama of Tibet, but now it is the Russian Government which names him. The fixed residence of the Lama is at the distance of a league from Astrakhan, at Bazar Kalmouke, by the shore of the Volga. Every summer the Lama quits his residence to make the tour of the Steppes. The lower clergy are very numerous, and are subdivided into different categories, which differ from one another, not by the degree of power they possess, but by the particular and proper attributes and duties of each category.

All the ghelungs or priests are exempt from taxes, and subsist upon the offerings they receive from the Nohyons, the Zaisanghs, and the people. These offerings consist of cattle, different objects, and money, and are ordinarily carried to the profit of the temple Kharoul; but they pass entirely into the hands of the Ghelongs, who have also many other sources of revenue. Thus, for example, they exercise medicine among the Kalmucks, and, notwithstanding their ignorance in this science, they nevertheless enjoy a much greater confidence among the population than any physician appointed by government.

A ghelung being called to a sick person, begins by giving him soup 
to drink, pure water, or he prepares the most, ordinary medicaments for him; and for nothing but this he frequently deprives the poor Kalmuck of all that he has, under the pretext of the offerings demanded for the bourkhans, the intervention of which is indispensable to procure the cure of the sick. If it is a rich maan who becomes ill, then there are many ghelungs who take charge of his treatment. They do not fail to take away all that their client possesses-his treasures, flocks, and last of all his kibitka-and all this under the pretext of offerings for the Khouroul. Notwithstanding all these sacrifices, it ordinarily happens that the sick man dies, leaving all his family in complete poverty.

The principal duty of the ghelungs is limited to the religious practices of their idolatry. This service usually passes in the Khouroul, for which every common kibitka may serve. Their divine service consists in the united ghelungs reciting - to the sounds of little bells, metallic plates, tambours, and gigantic trumpets-fragments of prayers, which they read from their sacred books, for the most part incomprehensible to themselves. A ghelung never voluntarily speaks upon matters relating to his religion, and if any one of his people questions him upon this subject, he never replies, giving for his reason that it is a sin to speak about religion.

Among ghelungs, the Zourkhatches, who are occupied with the composition of the Calendars, enjoy a very distinguished authority. The chronology of the Kalmucks does not consist in reckoning the years setting out from a certain memorable date; but they count by cycles each of twelve years, to which they give a particular name of such and such an animal. The year is composed of thirteen months, each of which also bears the name of an animal. Thus the first month in the year, which corresponds to our December, is called the tiger month; the months which follow are those of the hare, the dragon, the serpent, the horse, the goat, the ape, the fowl, the dog, the piq, the mouse, and the cow. One of the months returns twice, and that is the thirteenth of the year. Each month has thirty days, and the week has seven.

The Ghelongs-Zourkhatches are greatly respected by their confrères, on account of their spiritual functions, and they exercise a great influence upon the whole population. It is these who are specially addressed to fix the day propitious to celebrate marriage, or to point out the kind of funeral proper for a person dead. In this last circumstance they conform to the rank, more or less important, of the deceased, or, to speak more correctly, to the greater or smaller number of sheep which the relations offer for the Khouroul. The more liberal the offering, the more distinguished is the sepulture. But since, for example, the relatives of a Zaisangh or of a Noyhon have more means for making rich offerings, their bodies are ordinarily destined to be burned, whilst the corpse of a poor man is simply interred, or even abandoned in the midst of the Steppe, to become the prey of wild animals.

The principal evil arising from this great influence of the ghelungs 
over the Kalmuck population is, that it is opposed to every civilising effort ; this is why all the attempts of the government to convert the Kalmucks to Christianity, and to induce them to abandon their nomade life, have hitherto almost entirely failed. Moreover, the nature of the country occupied by the Kalmucks is greatly opposed to their being able to establish themselves in colonies.

A certain traveller very judiciously made this remark, that if it could be proposed to all the academies of Europe, to point out the best means to convert those enormous and sterile deserts, which are completely lost for agriculture, intu habitable and productive lands ; they would with difficulty find a more practical solution of this problem than that put in execution by the Kalmucks. But, in fact, with those poor herbs, so thin and so arid, which they find in these enormous wastes, burnt up by the sun, the Kalmucks nourish millions of horses, of cows, of goats, and of camels, and transform these sterile districts into a true and rich staple of Russia. By making a great trade of the wool and hair, of the fat, of the skins, and the pelts, the Kalmucks contribute to furnish illumination and defence against cold to a great portion of the northern provinces of the empire. In this particular the Kalmucks play a very important economical part.

This interesting and full description of the peculiarities of the Russian Kalmucks displays the usual great anthropological phenomenon of persistency of race character; and is, at the same time, an apt commentary upon the dogma of "the wisdom of the East." The picture of priestly medicine is somewhat re-assuring to the Western world. The most elaborate treatise upon the Kalmucks is that of S. P. Pallas, which is contained in his "Sammlungen historischer Nachrichten über die Mongolischen Völkerschaften," St. Petersburgh, 1776. Two vols. quarto. This work is illustrated with numerous large plates, exhibiting the life of the Kalmucks.

\section{J. KOPERNICKI.}

Description of Remains from the Dayr Már Músa el Habashi. By C. Curter Blake, Duct. Sci., F.G.S., Hon. Mem. A. I., Lecturer on Comparative Anatomy, Westminster Hospital (referred to at page 332 ).

The five skulls before us belong to two broad divisions, to the first of which appertain skulls 1, 2, 4; and to the second one 3 and 5. Only one of these skulls possesses the lower jaw attached.

Skull 1.- This large and powerful brachycephalous skull, supposed by Captain Burton to have belonged to a priest, is remarkable for the characters of extreme height and shortness. It is asymmetrical, there being a slight flattening on the right side. All the sutures are open, with the exception of the lower part of the coronal, and there is a large Wormian bone separating the alisphenoid from the parietal on the right side. On the left, the junction between the alisphenoid and parietal has been so short, that the frontal and temporal bones have almost joined. The coronal suture is not very completely denticulated. 